VASCO TÚLIO DE MOURA GOMES

Caracterização fenotípica e genotípica de cepas de Salmonella enterica isoladas de carne suína no município de São Paulo 


\section{VASCO TÚLIO DE MOURA GOMES}

Caracterização fenotípica e genotípica de cepas de Salmonella enterica isoladas de carne suína no município de São Paulo

Tese apresentada ao Programa de Pós-Graduação em Epidemiologia Experimental Aplicada às Zoonoses da Faculdade de Medicina Veterinária e Zootecnia da Universidade de São Paulo para obtenção do Título de Doutor em Ciências.

\section{Departamento:}

Medicina Veterinária Preventiva e Saúde Animal

Área de concentração:

Epidemiologia Experimental Aplicada às Zoonoses

Orientador:

Profa. Dra. Andrea Micke Moreno 
Autorizo a reprodução parcial ou total desta obra, para fins acadêmicos, desde que citada a fonte.

DADOS INTERNACIONAIS DE CATALOGAÇÃO NA PUBLICAÇÃO

(Biblioteca Virginie Buff D’Ápice da Faculdade de Medicina Veterinária e Zootecnia da Universidade de São Paulo)

Caracterização fenotípica e genotípica de cepas de Salmonella enterica isoladas de carne suína no município de São Paulo / Vasco Túlio de Moura Gomes. -- 2017.

72 f. : il.

Tese (Doutorado) - Universidade de São Paulo. Faculdade de Medicina Veterinária e Zootecnia. Departamento de Medicina Veterinária Preventiva e Saúde Animal, São Paulo 2017.

Programa de Pós-Graduação: Epidemiologia Experimental Aplicada às Zoonoses.

Área de concentração: Epidemiologia Experimental Aplicada às Zoonoses.

Orientador: Profa. Dra. Andrea Micke Moreno. 


\section{RESUMO}

GOMES VTM. Caracterização fenotípica e genotípica de cepas de Salmonella enterica isoladas de carne suína no município de São Paulo. [Phenotypic and genotypic characterization of strains of Salmonella enterica isolated from pork in São Paulo city]. 2017. 72 f. Tese (Doutorado em Ciências) - Faculdade de Medicina Veterinária e Zootecnia, Universidade de São Paulo, São Paulo, 2017.

Atualmente, a salmonelose representa uma das zoonoses de maior importância em Saúde Pública no mundo, em razão da alta endemicidade, mortalidade, e dificuldade do seu controle. No município de São Paulo, é possível encontrar diferentes realidades no que se diz respeito às boas práticas de produção e ao controle de qualidade dos produtos de origem animal, principalmente quando se considera os pontos de venda direta ao consumidor. Os objetivos do presente estudo foram avaliar a presença de Salmonella entérica em cortes de carne suína vendidos em mercados municipais, açougues e mercados de pequeno porte distribuídos nas cinco regiões do município de São Paulo. As estirpes isoladas foram caracterizadas quanto ao sorotipo, perfil de resistência a antimicrobianos, perfil genotípico através da eletroforese em campo pulsado (PFGE) e do polimorfismo do comprimento de fragmentos amplificados (AFLP). A partir dos 394 cortes de carne avaliados $6 \%$ foram positivos para o isolamento de $S$. enterica. Dentre os 111 estabelecimentos examinados, $14,4 \%$ apresentaram pelo menos um corte de carne positivo. Dentre as 60 estirpes selecionadas para caracterização, os sorotipos identificados foram Typhimurium (33,3\%), London (26,7\%), Brandenburg (10,0\%), Schwaezengrund $(8,3 \%)$, Derby $(8,3 \%)$, Infantis $(6,7 \%)$, Javiana $(6,7 \%)$. A determinação da concentração inibitória mínima indicou as seguintes frequências de resistência antimicrobiana: azitromicina (100\%), sulfametoxazol (98,3\%), ampicilina $(50 \%)$, cloranfenicol $(41,7 \%)$, tetraciclina $(40 \%)$, ácido nalidixico $(21,7 \%)$, gentamicina $(16,7 \%)$, trimetoprim (15\%) e ciprofloxacina (5\%). Todos os isolados foram sensíveis à cefotaxima, ceftazidima, meropenem e tigeciclina. Multirresistência foi identificada em $58,3 \%$ das estirpes avaliadas. A caracterização das estirpes pela PFGE e pelo AFLP revelou uma tendência a agrupar os isolados de acordo com a origem e com os sorotipos. A partir do sequenciamento do genoma de 11 estirpes foi possível identificar os STs, a presença de genes de resistência e de ilhas de patogenicidade. 
Os dados obtidos foram discutidos frente aos perfis descritos de estirpes de Salmonella entérica oriundas de criações de suínos e casos de infecção alimentar relatados no país e no exterior.

Palavras-chave: Salmonella entérica. Resistência. Carne suína. Genoma. PFGE. 
GOMES VTM. Phenotypic and genotypic characterization of strains of Salmonella enterica isolated from pork in São Paulo city. [Caracterização fenotípica e genotípica de cepas de Salmonella enterica isoladas de carne suína no município de São Paulo]. 2017. 72 f. Tese (Doutorado em Ciências) - Faculdade de Medicina Veterinária e Zootecnia, Universidade de São Paulo, São Paulo, 2017.

Currently, salmonellosis represents one of the most important zoonoses in Public Health in the world, due to the high endemicity, mortality, and difficulty of its control. In the city of São Paulo, it is possible to find different realities regarding good production practices and quality control of animal products, especially when considering the points of direct sales to the consumer. The objectives of the present study were to evaluate the presence of Salmonella enterica in pork cuts sold in municipal markets, butchers and small markets distributed in the five regions of the city of São Paulo. Isolated strains were characterized for serotype, antimicrobial resistance profile, genotypic profile through pulsed field electrophoresis (PFGE) and amplified fragment length polymorphism (AFLP). From the 394 meat cuts evaluated $6 \%$ were positive for isolation of $S$. enterica. Among the 111 establishments examined, $14.4 \%$ had at least one positive meat cut. Among the 60 strains selected for characterization, the identified serotypes were Typhimurium (33.3\%), London (26.7\%), Brandenburg (10.0\%), Schwaezengrund (8.3\%), Derby (8.3\%), Infantis $(6.7 \%)$ andJaviana (6.7\%). Determination of the minimum inhibitory concentration indicated the following frequencies of antimicrobial resistance: azithromycin (100\%), sulfamethoxazole (98.3\%), ampicillin (50\%), chloramphenicol (41.7\%), tetracycline (40\%), nalidixic acid (21.7\%), gentamicin (16.7\%), trimethoprim (15\%) and ciprofloxacin (5\%). All isolates were sensitive to cefotaxime, ceftazidime, meropenem and tigecycline. Multiresistance was identified in $58.3 \%$ of the strains evaluated. Characterization of the strains by PFGE and AFLP revealed a tendency to group the isolates according to the origin and the serotypes. From the genome sequencing of 11 strains it was possible to identify STs, presence of resistance genes and pathogenicityislands. The data obtained were discussed in relation to the described profiles of S.enterica strains from pig herds and cases of food infection reported in the country and abroad.

Keywords: Salmonella enteric. Resistance. Pork cuts. Genome. PFGE. 


\section{INTRODUÇÃO}

As infecções por bactérias do gênero Salmonella apresentam importância mundial tanto na produção de carnes quanto em saúde pública. Surtos de salmonelose são frequentemente associados ao consumo de ovos e carne de frango, entretanto, nos últimos anos, houve um aumento no número de casos de infecção humana relacionados ao consumo de produtos de origem suína (FEDORKA-CRAY et al., 1994; CASTAGNA et al., 2004a; CASTILLO; MARTÍNEZ; APODACA, 2008).

Suínos podem ser infectados pela grande maioria dos sorotipos de Salmonella, não exibindo sinais clínicos da doença, porém, são portadores que eliminam a bactéria de forma intermitente ao longo da cadeia produtiva. Epidemiologicamente, estes indivíduos são importantes pela difícil identificação e responsáveis pela contaminação cruzada de carcaças e subprodutos durante o abate (FEDORKA-CRAY,1996; BESSA; COSTA; CARDOSO, 2004).

Devido à importância desse patógeno nas granjas, abatedouros e no produto final, a escolha e padronização de técnicas que permitam a tipificação de amostras e sirvam como ferramenta para rastrear isolados em estudos epidemiológicos torna-se fundamental, pois técnicas adequadas permitem caracterizar e discriminar linhagens de Salmonella na cadeia de produção e em surtos de infecção humana.

Os objetivos do presente estudo foram o isolamento de Salmonella enterica em cortes de carne suína provenientes de mercados municipais, açougues e mercados de pequeno porte distribuídos nas cinco regiões do município de São Paulo. Caracterização fenotípica e genotípica dos isolados quanto ao sorotipo, perfil de resistência a antimicrobianos, perfil genotípico pela eletroforese em campo pulsado (PFGE), pelo polimorfismo do comprimento de fragmentos amplificados (AFLP) e sequenciamento do genoma bacteriano de algumas estirpes selecionadas. Os dados obtidos através da caracterização fenotípica e genotípica das cepas serão confrontados para a possível identificação de marcadores epidemiológicos e de virulência. 


\section{CONCLUSÕES}

- A presença de Salmonella enterica em carne suína é um problema presente em estabelecimentos do município de São Paulo;

- Foram identificados sete sorotipos diferentes dentre as amostras de carne suína avaliadas, sendo a maioria destes previamente descrita em suínos, ambientes de granjas ou abatedouros;

- A maioria dos isolados apresentou multirresistência a antimicrobianos de interesse no tratamento da Salmonelose em humanos.

- Os padrões de resistência foram semelhantes aos previamente descritos no Brasil e no mundo para estirpes de Salmonella de origem suína.

- A sorotipagem molecular foi uma ferramenta útil na caracterização das estirpes avaliadas, com alta concordância em relação à soroaglutinação e ao sequenciamento genômico.

- As estirpes foram discriminadas pelas técnicas genotípicas baseadas em restrição enzimática com tendência a agrupamento por sorotipo e mercado de origem;

- O sequenciamento genômico permitiu a análise de várias características relevantes das estirpes estudadas como identificação de sorotipo, genes de resistência, STs e ilhas de patogenicidade. 


\section{REFERÊNCIAS}

ACHTMAN, M., J. WAIN, F.-X. WEILL, S. NAIR, Z. ZHOU, V. SANGAL, M. G., KRAULAND, J. L. HALE, H. HARBOTTLE, A. UESBECK, G. DOUGAN, L. H. HARRISON, S. BRISSE; S. ENTERICA ML ST STUDY GROUP. 2012. Multilocus sequence typing as a replacement for serotyping in Salmonella enterica. Plos Pathog, v. 8, n. 6, p. 1-19, Jun. 2012.

AGBAJE, M.; BEGUM, R. H.; OYEKUNLE, M. A.; OJO, O. E.; ADENUBI, O. T. Evolution of Salmonella nomenclature: a critical note. Folia Microbiologica, v. 56, n. 6, p. 497-503, 2011.

ALGINO, R. J.; BADTRAM, G. A.; INGHAM, B. H.; INGHAM, S. C. Factors associated with Salmonella prevalence on pork carcasses in very small abattoirs in Wisconsin. Journal of Food Protection, v. 72, p. 714-721, 2009.

ARGUELLO, H.; CARVAJAL, A.; COLLAZOS, J. A.; GARCIA-FELIZ, C.; RUBIO, P. Prevalence and serovars of Salmonella enterica on pig carcasses, slaughtered pigs and the environment of four Spanish slaughter houses. Food Reserarch International, v.45, p. 905-912, 2012.

ASHTON, P. M.; NAIR, S.; PETERS, T. M.; BALE, J. A.; POWELL, D. G.; PAINSET, A.; TEWOLDE, R.; SCHAEFER, U.; JENKINS, C.; DALMANN, T. J.; PINNA, E. M.; GRANT, K. A. Identification of Salmonella for public health surveillance using whole genome sequencing. Peerj, v. 4, p. 1-18, Apr. 2016.

BALE, J.; MEUNIER, D.; WEILL, F. X.; DE PINNA, E.; PETERS, T.; NAIR, S. Characterization of new Salmonella serovars by whole-genome sequencing and traditional typing techniques.Journal of Medical Microbiology, v. 65, n. 10, p. 1074-1078, 2016.

BARRETT, T. J.; GERNER-SMIDT, P.; SWAMINATHAN, B. Interpretation of pulsedfield gel electrophoresis patterns in foodborne disease investigations and surveillance. Foodborne pathogens and disease, v. 3, n. 1, p. 20-31, 2006.

BERENDS, B. R.; URLINGS, H. A. P.; SNIJDERS, J. M .A.; VAN KNAPEN, F. Identification and quantification of risk factors in animal management and transport regarding Salmonella spp. in pigs. International Journal of Food Microbiology, v.30, p. 37-53, 1996.

BESSA, M. C.; COSTA, M.; CARDOSO, M. Prevalência de Salmonella sp em suínos abatidosem frigoríicos do Rio Grande do Sul. Pesquisa Veterinária Brasileira, v. 24, n. 2, p. 80-84, 2004.

BRADEN, C. R. Salmonella enterica serotype Enteritidis and Eggs: a national epidemic in the United States. Clinical Infectious Diseases, Chicago, v. 43, n. 4, p. 512-517, 2006. 
BRENNER, F.W.; VILLAR, R. G.; ÂNGULO, F. J., TAUXE, R.; SWAMINATHAN, B. Salmonella Nomenclature. Journal of Clinical Microbiology, v.38, n.7, p. 24652467, 2000.

BONARDI, S.; BASSI, L.; BRINDANI, F.; D'INCAU, M.; BARCO, L.; CARRA, E.; PONGOLINI, S. Prevalence, characterization and antimicrobial susceptibility of Salmonella enterica and Yersinia enterocolitica in pigs at slaughter in Italy. International Journal of Food Microbiology, v. 163, p. 248-257, 2013.

BOOM, R.; SOL, C. J.; SALIMANS, M. M.; JANSEN, C. L.; WERTHEIM-VAN DILLEN, P. M.; VAN DER NOORDAA, J. Rapid and simple method for purification of nucleic acids. Journal of Clinical Microbiology, v.28, n.3, p. 495-503, 1990.

CAI, Y.; TAO, J.; JIAO, Y.; FEI, x; ZHOU, I.; WANG, Y.; ZHENG, H.; PAN, Z.; JIAO, $X$. Phenotypic characteristics and genotypic correlation between Salmonella isolates from a slaughterhouse and retail markets in Yangzhou, China. International Journal of Food Microbiology, v. 222, p. 56-64, Apr. 2016.

CARDOSO, M. Doenças transmitidas por alimento de origem suína, Porto Alegre, RS. In: I SIMPÓSIO UFRG SOBRE MANEJO, REPRODUÇÃO E SANIDADE SUÍNA, 256., 2006, Porto Alegre. Anais... Porto Alegre: Faculdade de Veterinária, Universidade Federal do Rio Grande do Sul, 2006.

CARDOSO, T. G.; CARVALHO, V. M. Foodborne disease caused by Salmonella spp. Revista Instituto Ciência da Saúde, v. 24, n. 2, p. 95-101, 2006.

CASTAGNA, S.M.F.; SCHWARZ, P.; CANAL, C.W.; CARDOSO, M. Prevalência de suínos portadores de Salmonella sp. ao abate e contaminação de embutidos tipo frescal. Acta Scientiae Veterinariae, v. 32, n. 2, p. 141-147, 2004a.

CASTAGNA; S. M. F.; SCHWARZ, P.; CANAL, C. W.; CARDOSO, M. Presença de Salmonella sp. no trato intestinal e em tonsilas/linfonodos submandibulares de suínos ao abate. Arquivo Brasileiro de Medicina Veterinária e Zootecnia, v. 56, n. 3, p. 300-306, 2004b.

CASTILLO, A. C. G.; MARTínEZ, L. H. P.; APODACA, N. L. C. Salmonellosis and campylobacteriosis the most prevalent zoonosis in the world. Veterinária México, v. 39, n. 1, p. 81-90, 2008.

CDC. Centers for Diseases control and Protection. 2007. Disponível em: $<$ http://www.cdc.gov/ncidod/dbmd/diseaseinfo/salmonellosis_g.htm>. Acesso em: 05 set 2016.

CLARKE, R.C; GYLES C.L. Salmonella. In: GYLES, C.L.; CHARLES, O.T.

Pathology Bacterial Infection Animal. 2. ed. Ames: lowa State University, p.133153, 1993.

CLEMENTE, L.; MANAGEIRO, V.; FERREIRA, E.; JONES-DIAS, D.; CORREIA, I.; THEMUDO, P.; ALBUQUERQUE, T.; CANICA, M. Occurrence of extendedspectrum $\beta$-lactamases among isolates of Salmonella enterica subsp. enterica from 
food-producing animals and food products, in Portugal. International Journal of Food Microbiology, v. 167, n. 2, p. 221-228, 2013.

CLSI. Performances standards for antimicrobial disk and dilution susceptibility tests for bacteria isolated from animals; Aproved standard- Second Edition. NCCLS document M31-A3. 2008. USA.

CLSI. Performances standards for antimicrobial disk and dilution susceptibility tests for bacteria isolated from animals, VET01S, $3^{\text {rd }}$ edition, Wayne, PA, USA, 2015.

CLSI. Performances standards for antimicrobial disk and dilution susceptibility tests for bacteria isolated from animals, M1000S, 26 ${ }^{\text {rd }}$ edition, Wayne, PA, USA, 2016.

D'AOUST, J. Salmonella and the international food trade. International Journal of Food Microbiology, Amsterdan, v.24, p. 11-31, 1994.

D'AOUST, J. Salmonella species In: Doyle, M. P.; BEUCHAT, L.R.; MONTVILLE, T. Journal Food Microbiology. Washington, ASM Press, 1997, p. 129-158.

DOMÉNECH, E.; JIMÉNEZ-BELENGUER, A.; PÉREZ, R.; FERRÚS, M. A.; ESCRICHE, I. Risk characterization of antimicrobial resistance of Salmonella in meat products. Food Control, v. 57, p. 18-23, Nov. 2015a.

DOMÉNECH, E.; JIMENEZ-BELENGUER, A.; AMOROS, J. A.; FERRUS, M. A.; ESCRICHE, I. Prevalence and antimicrobial resistance of Listeria monocytogenes and Salmonella strains isolated in ready-to-eat foods in Eastern Spain. Food Control, v. 47, p. 120-125, Jan. 2015b.

DUGGAN, S. J.; MANNION, C.; PRENDERGAST, D. M.; LEONARD, N.; FANNING, S.; GONZALES-BARRON, U., EGAN, J.; BUTLER, F.; DUFFY, G. Tracking the Salmonella status of pigs and pork from lairage through the slaughter process in the Republic of Ireland. Journal of Food Protection, v. 73, p. 2148-2160, 2010.

DUIM, B.; WASSENAAR, T. M.; RIGTER, A.; WAGENAAR, J. A. High-resolution genotyping of Campilobacter strains isolated from poultry and humans with AFLP fingerprinting. Applied and Enviromental Microbiology, v. 65, n. 6, p. 2369-2375, Jun. 1999.

$E F S A / E C D C$. The European Union summary report on trends and sources of zoonoses, zoonotic agents and food-borne outbreaks in 2012. EFSA Journal, 2014. Doi 10.2903/j.efsa.2014.3547. Disponível:

<http://www.efsa.europa.eu/en/efsajournal/pub/3547.htm Accessed March 2014> Acesso em 20 Nov 2015.

ECONOMIC RESEARCH SERVICE. Cost Estimates of Foodborne Illnesses. U.S. Department of Agriculture (USDA), 2013. Disponível em <http://ers.usda.gov/dataproducts/cost-estimates-of-foodborne-illnesses.aspx> Acesso em 20 Nov 2015. 
FAO. Food and Agriculture Organization of the United Nations. 2008. Disponível em: < http://www.fao.org/index_en.htm> Acesso em 25 Jan. 2013.

FEDORKA-CRAY, P. J.; WHIPP, S. C.; ISAACSON, R. E.; NORD, N.; LAGER, K. Transmission of Salmonella typhimurium to swine. Veterinary of Microbiology, v.41, p. 333-344, 1994.

FEDORKA-CRAY, P.J. The connection between Salmonella, swine, and food safety. In: PROCEEDINGS OF SWINE CONFERENCE, 45., 1996, Nebrasca. Anais... Nebrasca: Lincoln, 1996.

FEDORKA-CRAY, P.; HOGG, A.; GRAY, J. T.; LORENZEN, K.; VELASQUEZ, J.; BEHREN, P. V. Feed and feed trucks as sources of Salmonella contamination in swine. Swine Health Production, v.5, p.189-193, 1997.

FERRARI, R.; GALIANA, A.; CREMADES, R.; RODRIGUEZ, J. C.; MAGNANI, M.; TOGNIM, M. C. B.; OLIVEIRA, T. C. R. M.; ROYO, G. Plasmid-mediated quinolone resistance (PMQR) and mutations in the topoisomerase genes of Salmonella enterica strains from Brazil. Brazilian Journal of Microbiology, v. 44, n. 2, p. 657-662, 2013.

FORTES, T. P.; FAGUNDES, M. Q.; VASCONCELLOS, F. A.; TIMM, C. D.; SILVA, É. F. DA. Salmonella entérica pathogenicity islands: a review. Revista Instituto Adolfo Lutz, v. 71, n. 2, p. 219-227, 2012.

GALLAND, J. C.; HOUSE, J. K.; HYATT, D. R.; HAWKIN, L. L.; ANDERSON, N. V.; IRWIN, C. K.; SMITH, B. P. Prevalence of Salmonella in beef feeder steers as determined by bacterial culture and ELISA serology. Veterinary of Microbiology, v.76, p.143-151, 2000.

GIROTTO, A. F. Suínos: Análise do Desempenho Atual. Anuário 2006 da Suinocultura Industrial, n.1, ano 28, p. 16-23, 2006.

GUIBOURDENCHE, M.; ROGGENTIN, P.; MIKOLEIT, M.; FIELDS, P. I.; BOCKEMUHL, J.; GRIMONT, P.A.D.; WEILL, F. Supplement 2003-2007 (No. 47) to the White-Kauffmann-Le Minor scheme. Research in Microbiology, v. 161, n. 1, p. 26-29, 2010.

HABU, Y.; FUKUDA-TANAKA, S.; HISATOMI, Y.; LIDA, S. Amplified restriction fragment length polymorphism- based mRNA fingerprinting using a single restriction enzyme that recognizes a 4-bp sequence. Biochemistry Biophysic Research Communication, v. 234, n. 2, p. 516-521, May. 1997.

HALD, T.; WEGENER, H. C. Quantitative assessment of the sources of human salmonelosis attributable to pork. In: INTERNATIONAL SYMPOSIUM ON THE EPIDEMIOLOGY AND CONTROL OF SALMONELLA IN PORK, 205., 1999, Washington. Anais... Urbana-Champaing: University of Ilinois, 1999. 
HALL, T. A. BioEdit: a user-friendly biological sequence alignment editor and analysis program for Windows 95/98/NT. Nucleic Acids Symposium, n. 41, p. 9598, 1999.

HANSEN, T. B.; CHRISTENSEN, B. B.; AABO, S. Salmonella in Pork Cuttings in Supermarkets and Butchers' Shops in Denmark in 2002 and 2006. Zoonoses and Public Health, v. 57, n. 1, p. 23-29, Nov 2010.

HOLT, J. G; KRIEG, N. R.; SNEATH, P. H. A. Bergey's manual of determinative bacteriology. 9.ed. Baltimore : Williams \& Wilkins, 1994. Cap.5: Facultative anaerobic Gram-negative rods: p.175-189.

HUNT, M. L.; ADLER, B.; TOWNSEND, K. M. The molecular biology of Pasteurella multocida. Veterinary Microbiology, v. 72, n. , p. 3-25, 2000.

HUNTER, P. R.; GASTON, M. A. Numerical index of the discriminatory ability of typing systems: an application of Simpson's index of diversity. Journal of Clinical Microbiology, v. 26, n. 11, p. 2465-2466, 1988.

JEAN-GILLES, B., J.; CHENG, C. M.; CHEN, K. S.; EWING, L.; WANG, H.; AGPAOA, M. C.; HUANG, M. C.; DICKEY, E.; DU, J. M.; WILLIAMS-HILL, D. M.; HAMILTON, B.; MICALLEF, S. A.; ROSENBERG GOLDSTEIN, R. E.; GEORGE, A.; JOSEPH, S. W.; SAPKOTA, A. R.; JACOBSON, A. P.; TALL, B. D.; KOTHARY, M. H.; DUDLEY, K.; HANES, D. E. The evaluation of a PCR-based method for identification of Salmonella enterica serotypes from environmental samples and various food matrices. Food Microbiology, v. 31, n. 2, p. 199-209, 2012.

JOENSEN, K.G.; SCHEUTZ, F.; LUND, O.; HASMAN, H.; KAAS, R. S.; NIELSEN, E. M.; AARESTRUP, F. M. Real-time whole-genome sequencing for routine typing, surveillance, and outbreak detection of verotoxigenic Escherichia coli. Journal of Clinincal Micobiology, v. 52, n. 5, p. 1501-1510, 2014. 2014.

KEELARA, S.; SCOTT, H. M.; MORROW WW. M.; GEBREYS, W. A.; CORREA, M.; NAYAK, R.; STEFANOVA, R.; THAKUR, S. Longitudinal study of distributions of similar antimicrobial-resistant Salmonella serovars in pigs and their environment in two distinct swine production systems. Applied and Environmental Microbiology, v. 79, n. 17, p. 5167-5178, Set. 2013.

KICH, J. D.; MORES, N.; PIFFER, I. A.; COLDEBELLA, A.; AMARAL, A.; RAMMINGER, L.; CARDOSO, M. Fatores associados a soroprevalência de Salmonella em rebanhos comerciais de suínos. Ciência Rural, v. 35, n.2, p. 398405, 2004.

$\mathrm{KICH}$, J. D. Salmonelose. In: SOBESTIANSKY, J.; BARCELLOS, D. (Eds). Doença dos Suínos: Goiânia, p.196-203, 2007. 
KICH, J. D.; COLDEBELLA, A.; MORÉS, N.; NOGUEIRA, M. G.; CARDOSO, M.; FRATAMICO, P. M.; CALL, J. E.; FEDORKA-CRAY, P.; LUCHANSKY, J. B. et al. Prevalence, distribution, and molecular characterization of Salmonella recovered from swine finishing herds and a slaughter facility in Santa Catarina, Brazil. International Journal of Food Microbiology, v. 151, n. 3, p. 307-313, 2011.

KIDGELL, C.; REICHARD, U.; WAIN, J.; LINZ, B.; TORPDAHL, M.; DOUGAN, G.; ACHTMAN, M. Salmonella typhi the causative agent of typhoid fever, is approximately 50,000 years old infection. Infection Genetic and Evolution, v. 12, p. 39-45, Apr. 2002.

KIM, S.; FRYE, J. G.; HU, J.; FEDORKA-CRAY, P. J.; GAUTOM, R.; BOYLE, D. S. Multiplex PCR-based method for identification of common clinical serotypes of Salmonella entérica subsp. entérica. Journal of Clinical Microbiology, v. 44, p. 3608-3615, 2006.

KOTTWITZ,L. B. M.; BACK, A.; LEÃO, J. A.; ALCOCER, I.; KARAN, M.; OLIVEIRA, T. C. R. M. Contaminação por Salmonella spp. em uma cadeia de produção de ovos de uma integração de postura comercial. Arquivo Brasileiro de Medicina Veterinária e Zootecnia, v. 60, n. 2, 2008.

KUHNS M, ZAUTNER AE, RABSCH W, ZIMMERMANN O, WEIG M, BADER, O.; GROB, U. Rapid discrimination of Salmonella enterica serovar Typhi from Other Serovars by MALDI-TOF mass spectrometry. Plos One, v. 7, n. 6, p. 1-6, 2012.

LARSEN, M. V.; COSENTINO, S.; RASMUSSEN, S.; FRIIS, C.; HASMAN, H.; MARVIG, R.L.; JELSBAK, L,.; SICHERITZ-PONTÉN, T.; USSERY, D. W.; AARESTRUP, F. M.; LUND, O. Multilocus sequence typing of total-genomesequenced bacteria. Journal of Clinical Microbiology, v. 50, p. 1355-1361, 2012.

LEEKITCHAROENPHON, P.; NIELSEN, E. M.; LUND, R. S.; AARESTRUP, F. M. Evaluation of whole genome sequencing for outbreak detection of Salmonella enteric. Plos One, v. 9, n.2, p. 1-11, Fev. 2014.

LETELLIER, A.; MESSIER, S.; QUESSY, S. Prevalence of Salmonella spp. And Yersinia enterocolitica in finishing swine at Canadian abattoirs. Journal of food Protection, v. 62, n.1, p. 22-25, 1999.

LIMA, C. E.; MORETTO, A. C.; RODRIGUES, R. L. Mercado de Carne Bovina no Brasil: Oferta e Demanda no período 2000 a 2009. In: 49 CONGRESSO BRASILEIRO DE ECONOMIA E SOCIOLOGIA RURAL, 228., 2011, Belo Horizonte. Anais... Belo Horizonte: Faculdade de Ciências Econômicas, 2011.

LI, Y. C.; PAN, Z. M.; KANG, X. L.; GENG, S. Z.; LIU, Z. Y.; CAI, Y. Q.; JIAO, X. A. Prevalence, characteristics, and antimicrobial resistance patterns of Salmonella in retail pork in Jiangsu Province, Eastern China. Journal of Food Protection, v. 77, p. 236-245, 2014.

LOPES, G. V.; PISSETTI, C.; DA CRUZ PAYÃO PELLEGRINI, D.; SILVA, L. E.; CARDOSO, M. Resistance Phenotypes and Genotypes of Salmonella enterica 
subsp. enterica Isolates from Feed, Pigs, and Carcasses in Brazil. Journal of Food Protection, v. 78, n. 2, p. 407-413, 2015.

MAJOWICZ, S.E.; MUSTO, J.; SCALLAN, E.; ANGULO, F.J.; KIRK, M.; O'BRIEN, S.J.; JONES, T.F.; FAZIL, A.; HOEKSTRA, R.M. The Global Burden of Nontyphoidal Salmonella Gastroenteritis. Clinical Infectious Diseases. v. 50, n. 6, p. 882-889, 2010.

MAPA, Ministério da Agricultura. 2016. Análise da agricultura e pecuária brasileira. 2016. Disponível em: <http://www.agricultura.gov.br>. Acesso em 17 de maio de 2016.

MCLAUCHLIN, J.; RIPABELLI, G.; BRETT, M. M.; THRELFALL,E. J.; Amplified fragment length polymorphism (AFLP) analysis of Clostridium perfringens for epidemiological typing, International Journal of Food Microbiology, v. 56, p. 21$28,2000$.

MCQUISTON, J. R.; PARRENAS, R.; ORTIZ-RIVERA, M.; GHEESLING, L.;

BRENNER, F.; FIELDS, P. I.; Sequencing and comparative analysis of flagellin gene flicC, FljB and flpA from Salmonella. Journal of Clinical Microbiology, v. 42, n. 5, p. 1923-1932, May. 2004.

MIHAIU, L.; LAPUSAN, A.; TANASUICA, R.; SOBOLU, R.; MIHAIU, R.; ONIGA, O.; MIHAIU, M. First study of Salmonella in meat in Romania. The Journal Infection Developing Countries, v. 8, p. 50-58, 2014.

MINISTÉRIO DA SAÚDE. Surtos de doenças transmitidas por alimentos no Brasil. 2016. Disponível em: <http://www.saude.gov.br/svs>. Acesso em 10 de dezembro de 2016.

MIRANDA, J. M.; MONDRAGON, A. C.; MARTINEZ, B.; GUARDDON, M.; RODRIGUEZ, J. A. Prevalence and antimicrobial resistance patterns of Salmonella from different raw foods in Mexico. Journal of Food Protection, v. 72, p. 966-971, 2009.

MORTIMER, C. K.; PETERS, T. M.; GHARDIA, S. E.; LOGAN, J. M.; ARNOLD, C. Towards the development of a DNA-sequence based approach to serotyping of Salmonella enterica. BMC Microbiology, v. 4, n. 31, p. 1-10, Aug. 2004.

NAIR, S.; WAIN, J.; CONNELL, S.; DE PINNA, E.; PETERS, T. Salmonella enterica subspecies II infections in England and Wales - the use of multilocus sequence typing to assist serovar identification. Journal of Medical Microbiology, v. 63, p. 831-834, Mar. 2014.

NAIR, S.; ASHTON, P.; DOUMITH, M.; CONNELL, S.; PAINSET, A.; MWAIQWISYA, S.; LANGRIDGE, G.; DE PINNA, E.; GODBOLE, G.; DAY, M. WGS for surveillance of antimicrobial resistance: a pilot study to detect the prevalence and mechanism of resistance to azithromycin in a UK population of non-typhoidalSalmonella. Journal of Antimicrobial Chemotherapy, v. 71, n. 12, p. 3400-408, 2016. 
NIELSEN, B.; BAGGESEN, D.; BAGER, F.; HAUGEGAARD, J.; LIND, P. The serological response to Salmonella sorotypes typhimurium and infantis in experimentally infected pigs: the time course followed with an indirect anti-LPS ELISA and bacteriological examinations. Veterinary of Microbiology, v. 47, p.205218, 1995.

POPOFF, M.Y.; LE MINOR, L. Antigenic formulae of the Salmonella sorotypes, $7^{\text {th }}$ revision. World Health Organization Collaborating Centre for Reference and Research on Salmonella, Pasteur Institute, Paris, France, 1997.

POPOFF, M., Y.; BOCKEMÜHL, J.; BRENNER, F. W. Supplement 1998 (no. 42) to the Kauffmann-White scheme. Research in Microbiology, v.151, p. 63-65, 1998.

POSSEBOM, F. S. Perfil molecular e resistência a antimicrobianos de Salmonella isolada em linfonodos mesentéricos de suínos. 2016. 58f. Dissertação (Mestre em Ciências) - Faculdade de Medicina Veterinária e Zootecnia, Universidade estadual Paulista, Botucatu, 2016.

PRENDERGAST, D. M.; DUGGAN, S. J.; FANNING, S.; CORMICAN, M.; GONZALES-BARRON, U.; BUTLER, F.; DUFFY, G. Prevalence and numbers of Salmonella spp.and Enterobacteriaceae on pork cuts in abattoirs in the Republic of Ireland. Journal of Applied Microbiology, v. 105, p. 1209-1219, 2008.

QUINN, P.J., CARTER, M. E.; MARKEY, B. K.; CARTER, G.R. Clinical Veterinary Microbiology, London: Wolfe Publishing, 648p, 1994.

RANIEI, M. L.; SHI, C.; MORENO, A. I. S.; DEN BAKKER, H. C.; WIEDMANN, M. Comparasion of typing methods with a new procedure based on sequence characterization for Salmonella serovar prediction. Journal of Clinical Microbiology, v. 51, n. 6, p. 1786-1897, Jun. 2013.

ROER, L.; HENDRIKSEN, R. S.; LEEKITCHAROENPHON, P.; LUKJANCENKO, O.; KAAS, R. S.; HASMAN, H.; AARESTRUP, F. M. Is the Evolution of Salmonella enterica subsp. enterica Linked to Restriction-Modification Systems?. Msystems, v. 1, n. 3, 2016.

ROLAND, K.; CURTISS, R.; SIZEMORE, D. Construction and evaluation of a delta cya delta crp Salmonella typhimurium strain expressing avian pathogenic Escherichia coli O78 LPS as a vaccine to prevent airsacculitis in chickens. Avian Diseases, v. 43, p. 429-441, 1999.

SALES, M. DE; ABRANTES, M. R.; OLIVEIRA, A. R. M.; SOARES, K. M. P.; MENDES, C. G.; LEITE, A. I.; SILVA, J. B. A. Avaliação da carne suína in natura comercializada em Mossoró-RN. Acta Vetrinária Brasilica, v. 7, n. 4, p. 306-310, 2013.

SANTOS, L. R.; NASCIMENTO, V. P.; FLORES, M. L. Salmonella enteritidis isoladas de amostras clínicas de humanos e de alimentos envolvidos em episódios de 
toxinfecções alimentares, ocorridas entre 1995 e 1996, no Estado do Rio Grande do Sul. Higiene Alimentar, v. 16, n. 102, p. 93-99, 2002.

SAVELKOUL, P. H. M.; AARTS, H. J. M.; DE HAAS, J.; DIJKSHOORN, L.; DUIM, B.; OTSEN, M.; RADEMAKER, J. L. W.; SCHOULS, L.; LENSTRA, J. A. Amplifiedfragment lenghtpolymorfism analysis: the state of an art. Journal of Clinical Microbiology, v. 37, n. 10, p. 3083-3091, Oct. 1999.

SCALLAN, E.; HOEKSTRA, R. M.; ANGULO, F. J.; TAUXE, R. V.; WIDDOWSON, M. A.; ROY, S. L.; JONES, J. L.; GRIFFIN, P. Foodborne Illness Acquired in the United States-Major Pathogens. Emerging Infectious Diseases, v. 17, n. 1, p. 7-15, 2011.

SCHMIDT, H.; HENSEL, M. Pathogenicity islands in bacterial pathogenesis. Clinical Microbiology Review, v. 7, p.14-56, 2004.

SCHWARTZ, D.C.;CANTOR, C.R. Separation of yeast chromosome-sized DNAs by pulsed field gradient gel electrophoresis. Cell 37, p. 67-75, 1984.

SCHWARTZ, K. J. Salmonellosis. In: STRAW, B.E.; D'ALLAIRE, S.; MENGELING, W.L. Diseases of Swine. Ames: lowa State University Press, 2000, p. 535-551.

SCHWARZ, S.; SILLEY, P.; SIMJEE, S.; WOODFORD, N.; VAN DUIJKEREN, E.; JOHNSON, A. P.; GAASTRA, W. Assessing the antimicrobial susceptibility of bacteria obtained from animals. Veterinary Microbiology, v.141, p.1-4, 2010.

SILVA, E. N.; DUARTE, A. Salmonella Enteritidis em aves: retrospectiva no Brasil. Revista Brasileira de Ciência Avícola, v. 4, n. 2, p. 85-100, 2002.

SILVA, L. E.; GOTARDI, C.; MOSTARDEIRO, P.; SANTIN, K.; VIZZOTO, R.; KICH, J.; NADVORNI, A; CARDOSO, M. Estudo longitudinal da infecção por Salmonella em um sistema integrado de produção de suínos. In: CONGRESSO DE VETERINÁRIOS ESPECIALISTAS EM SUÍNOS, 11., 2003, Goiânia.

Anais...Goiânia: Associação Brasileira de Veterinários Especialistas em Suínos, 2003. p. 62.

SJÖLUND-KARLSSON, M.; JOYCE, K.; BLICKENSTAFF, K.; BALL, T.; HARO, J.; MEDALHA, F. M.; FEDORKA-CRAY, P.; ZHAO, S.; CRUMP, J. A.; WHICHARD, J. M. Antimicrobial susceptibility to azithromycin among Salmonella enterica isolates from the United States. Antimicrobial Agents and Chemotherapy, v. 55, n. 9, p. 3985-3989, 2011.

STEVENS, M. P.; HUMPHREY T. J.; MASKELL, D. J. Molecular insights into farm animal and zoonotic Salmonella infections. Philosophical Transactions of the Royal Society, v. 364, p. 2709-2723, 2009.

STONE, G. G.; OBERST, R. D.; HAYS, M. P.; MCVEY, S.; GALLAND, J.; CURTSS, R.; KELLY, S. M.;CHEMGAPPA, M. Detection of Salmonella typhimurium from rectal swabs of experimentally infected beagles by short cultivation and PCR hybridization. Journal of Clinical Microbiology, v. 33, n. 5, p. 1292-1295, 1994. 
TESSARI, E. N. C.; CARDOSO, A. L. S. P.; KANASHIRO, A. M. I.; STOPPA, G. F. Z.; LUCIANO, R. L.; CASTRO, A. G. M. Ocorrência de Salmonella spp. em carcaças de frangos industrialmente processadas, procedentes de explorações industriais do Estado de São Paulo, Brasil. Revista Ciência Rural, v. 38, n. 9, p. 2557-2560, 2008.

TESSMANN, C.; ZOCCHE, F.; LIMA, A. S BASSANI, M.; LOPES, G. V.; SILVA, W. $P$. Ocorrência e perfil de sensibilidade a antibióticos de Salmonella spp. isolada em cortes de carne suína comercializados em feiras-livres de Pelotas-RS. Boletim do Centro de Pesquisa de Processamento de Alimentos, v. 26, n. 2, p. 307-313, 2008.

THAI, T. H.; HIRAI, T.; LAN, N.T.; YAMAGUCHI, R. Antibiotic resistance profiles of Salmonella serovars isolated from retail pork and chicken meat in North Vietnam. International of Journal Food Microbiology, v. 156, p. 147-151, 2012.

VAN BELKUM, A.; TASSIOS, P. T,; DIJKSHOORN, L.; HAEGGMAN, S.; COOKSON, B.; FRY, N. K.; FUSSINGG, V.; GREENH, J.; FEILI, E.; GERNERSMIDTJ, P.; BRISSEK, S.; STRUELENS, M. Guidelines for the validation and application of typing methods for use in bacterial epidemiology. Clinical Microbiol and Infections, v. 13, p.1-46, 2007.

VAN DER GAAG, M. A.; VOS, F.; SAATKAMP, H. W.; BOVEN, M. V.; BEEK, P. V.; HUIRNE, R.B. A state-transition simulation model for the spread of Salmonella in the pork supply chain. European Journal of Operations Research, v.156, p.782-798, 2004.

VARNAM, A. S. Salmonella: Foodborne pathogens. London: Wolfe Publishing, 1991, $462 \mathrm{p}$.

VOETSCH, A. C.; VAN GILDER, T. J.; ANGULO, F. J.; FARLEY, M. M.; SHALLOW, S.; MARCUS, R.; CIESLAK, P. R.; DENEEN, V. C.; TAUXE, R. V. Emerging infections program foodnet working group 2004 foodnet estimate of the burder of illness caused by nontyphoidal Salmonella infections in the United States. Clinical Infection Disease, v. 38, p. 127-134, 2004.

VOETSCH, A. C., VAN GILDER, T. J., ANGULO, F. J., FARLEY, M. M., SHALLOW, S., MARCUS, R.; CIESLAK, P. R.; DENEEN, V. C.; TAUXE, R. V. FoodNet estimate of the burden of illness caused by non typhoidal Salmonella infections in the United States. Clinical Infectious Diseases, n. 38, p. 127-134, 2004.

WEGENER, H. C.; BAGER, F. Pork as a source of human salmonellosis. In: $2^{\circ}$ Internacional Symposium on Epidemiology and Control of Salmonella in Pork, 8., 1997, Conpenhagen. Anais... Copenhagen, 1997.

WIERUP, M.; HÄGGBLOM, P. An assessment of soybeans and other vegetable proteins as source of Salmonella contamination in pig production. Acta Veterinaria Scandinavica, v. 54, n.15, p. 1-9, 2010. 
ZANKARI E.; HASMAN H.; COSENTINO S.; VESTERGAARD, M.; RASMUSSEN, S.; LUND, O.;AARESTRUP, F. M.; LARSEN, M. V. Identification of acquired antimicrobial resistance genes. Journal of Antimicrobial Chemotherapy, v. 67, n. 11, p. 6640-2644, 2012.

ZHANG, S.; YIN, Y.; JONES, M. B.; ZHANG, Z.; DEATHERAGE Kaiser, B. L.; DINSMORE, B. A. FITZGERALD, C.; FIELDS, P. I.; DENG, X. J. Salmonella serotype determination utilizing high-throughput genome sequencing data. Journal of Clinical Microbiology, v. 53, p. 1685-1692, May. 2015.

ZUCON, L. T. S. Caracterização fenotípica e genotípica de amostras de Salmonella spp. isoladas de suínos. 2008. 73 f. Tese (Doutorado em Ciências) Faculdade de Medicina Veterinária e Zootecnia, Universidade de São Paulo, São Paulo, 2008.

YOSHIDA, C. E.; KRUCZKIEWICZ, P.; LAING, C. R.; LINGOHR, E. J.; GANNON, V. P.; NASH, J. H.; TABOADA, E. N. The Salmonella in silico typing resource (SISTR): an open web-accessible tool for rapidly typing and subtyping draft Salmonella genome assemblies. Plos One, v. 11, n. 1, p. 1-17, 2016. 